\title{
European Court of Human Rights and Right to Respect for Family Life: The role of the best interests of the child in establishing equality between divorced parents.
}

\author{
Kyriaki Patsianta ${ }^{1}$ \\ Barrister
}

\begin{abstract}
This article discusses the concept of the best interests of the child forged by the European Court of Human Rights in cases concerning family life. The Strasbourg Court does not determine in a detailed way all the aspects of the child's best interests in a case presented before it. It forges its minimum content while the Member States are free to complete its construction. This European minimum content contains two branches: the conceptual principles and the methods of evaluation. An analysis on specific judgments of the Court regarding equality between divorced parents in parental rights allocation provides a concrete example of how these two branches are constructed by it. The alleged discriminatory treatment relates to issues like religion, sexual orientation, transsexualism.

Keywords: best interests of the child, European Court of Human Rights, right to respect for family life, divorce, equality, discrimination
\end{abstract}

Correspondence should be addressed to:

Kyriaki Patsianta, 16, Lepenioti Street, 38334, Volos, Greece

Contact:kpatsianta@gmail.com 


\section{Introduction}

This article explores the concept of the best interests of the child in the European Court of Human Rights case law regarding family life. It describes the European construction of this principle by the Strasbourg Court in cases concerning children and their parents. More specifically, this article presents how the child and family has become a European, rather than an internal, affair and the ways these two perspectives are balanced and combined together. It points out the place of the best interests concept in the ECtHR jurisprudence through the concrete example of cases relating to equality between divorced parents in parental rights allocation.

\section{Family and Child as Internal Affairs}

\section{Family law}

Definitions of 'family' from sociological, historical, anthropological, psychological, and ethnological perspectives are undeniably possible; it is more than clear that diverse approaches would result in various definitions. Consequently, it is absurd to imagine that one, and only one, definition could include all of these different perspectives from which family could be viewed (Théry, 2002). Despite the fact that everyone knows intuitively what a family is, one single definition, which would transcend this diversity of views, seems impossible (Vasseur - Lambry, 2000).

As its micrography, family is very important for society. It is its principal cell, the first one to welcome its members. Family is profoundly attached to society; it is connected to its structure, economic growth, political system and culture (Smychzynski, 1983). Society longs for family to function according to the dominant social and cultural reality (Smychzynski, 1983). Therefore, society attempts to elaborate rules that apply to the creation and function of family. Historically, these rules had the form of certain types of behaviour and oral traditions. Gradually, laws replaced all of these customs.

In European legal systems, family law is a branch of civil law ${ }^{2}$. It has three main features: first, family law regulations are leges cogentes; an individual cannot deviate from them. The obligatory aspect of family regulations pinpoints society's intention to impose its rules, to establish stability and security in family relationships and to put forward the family models that it has chosen for its members to follow. ${ }^{3}$

Second, family law regulations do not marginalise individuals' autonomy. Over the last several years, legislative reforms in several European countries gave space to 
personal choices concerning the creation and function of family relationships ${ }^{4}$. Third, family law has a strong national character. It is attached to society's culture and the family relationships that it regulates. Since each society is unique, even in a certain geographical space such as Europe, where the social and political evolution has been similar for each country, a different family model was established in each European society. Hence, the family law prevailing in every one of these societies is unique, given that it is connected to their specific characteristics (Arnaud, 1996).

Despite the fact that family law is greatly identified with the country to which it applies, there are similarities present in current principles of family legislation of different European countries (Papachristos, 1998). These include the principles of respect of personality, the equality of sexes, the best interests of the child, emanating to a great extent from the respect for LGBT rights, women's emancipation, the importance given to the protection of children that are reflected in marriage, divorce and parental authority regulations.

Although children did not enjoy any rights for quite a long time ${ }^{5}$, as their lives were entirely controlled by their parents, especially by fathers, the omnipotent pater familias, currently their rights are recognized. More specifically, the Convention on the Rights of the Child outlines the full range of rights belonging to children; the UN General Assembly adopted it on the $20^{\text {th }}$ November 1989 . Yet, even though the importance of children's rights enjoys vast recognition worldwide, their implementation is not flawless ${ }^{6}$.

In this context, the child is no longer an "object of property"; one could say that they have been transformed instead into an "object of desire" given the desire to become a parent by many who use every possible natural, scientific or legal method (Meulders Klein, 2003). More precisely, as far as a child's role in the family is concerned, it appears that nowadays "the centre of gravity" of the latter moves from conjugality to filiation (Lambert, 2002). Children are the privileged members of the family; their well-being is of high importance. As Roussel argues, their cradle is the heart of every home (1991).

\section{The best interests of the child}

The best interests principle is present in many European legal systems including in France (Donnier, 1959; Rubellin-Devichi, 1994) and Greece (Kounougeri-Manoledaki, 2008). In France, in particular, Dean Carbonnier maintained that the best interest of the child is a "magical concept" that "made all the institutions of family law unnecessary" (Fulchiron, 1996). 
Taking into consideration the two basic components of this principle, one sees that 'being a child' may be connected to a certain age limit which has not yet been reached. This definition, however, is vague and simplistic because the term 'child' also indicates a family relationship; that is, one is always someone's child regardless of our age (Dekeuwer-Défossez, 2004).

Further, definitions of the concept of the 'child' by different disciplines including psychology, psychoanalysis, and other social sciences have underlined its diversity (Hamadi, 2007). This diversity is important because a child does not correspond to a static image; his or her needs evolve throughout time (Habib, 1983). Thus, babies, young children, adolescents are all included in the concept of the 'child.'

Second, the term 'best interests' is equally difficult to define. It seems to include two dimensions, both a moral one and a material one (Conseil de l'Europe, 1990). However, it is not easy to separate these two dimensions since both influence the child's physical and psychological balance. The adjective 'best' that precedes the term 'interests' highlights a priority. The necessity to ensure the child's well-being in the best possible way gives crucial importance to his or her interests. Thus the phrase "the best interest of the child" acquires a distinctive dynamism, notably in comparison with terms such as "the interest of the father," "the interest of the mother," and "the interest of the grandparents." To put it differently, it is the term 'child' that gives a certain specificity and vibration to "best interests."

When family life is peaceful, the parents determine the best interests of their child. When family life is in crisis, legislation and courts intervene. The legislator establishes the great significance of this principle; the judge concretizes it. The best interests principle is the State's answer to the constant demand for children's protection (see Wolfson, 1992). It indicates the State's protective role towards children from every menace, even from the ones that come from their parents.

According to article 3 of the United Nations Convention on the Rights of the Child, ${ }^{7}$ which has been ratified by 196 States including the 47 Council of Europe Member States $^{8}$, the best interests of the child shall be a primary consideration in all actions concerning children, both in the public and private sphere. In its General Comment $\mathrm{N}^{\circ} 14$ (2013) on the right of the child to have his or her best interests taken as a primary consideration, the Committee on the Rights of the Child" notes that "the concept of the child's best interests is aimed at ensuring both the full and effective enjoyment of all the rights recognized in the Convention and the holistic development of the child." ${ }^{\prime 10}$ The 
Committee also specifies that the child's best interest is a threefold concept: "a substantive right: the right of the child to have his or her best interests assessed and taken as a primary consideration when different interests are being considered in order to reach a decision on the issue at stake...,; a fundamental, interpretative legal principle: if a legal provision is open to more than one interpretation, the interpretation which most effectively serves the child's best interests should be chosen....; a rule of procedure: whenever a decision is to be made that will affect a specific child, an identified group of children or children in general, the decision-making process must include an evaluation of the possible impact (positive or negative) of the decision on the child or children concerned...."11

\section{Family and Child as a European Affair}

\section{The basic text}

Going beyond a simple comparative study of European legal systems regarding family law in order to disclose their common features, a new, inventive source of family law which comes from the outside and appears to have the power to alter its strictly national character is the European Human Rights Law (De Lamy, 1998; Labayle, 2007). The basis of European Human Rights Law is the Convention for the Protection of Human Rights and Fundamental Freedoms. ${ }^{12}$ Its protocols are applied and interpreted by the European Court of Human Rights. The European Convention on Human Rights, inspired by the Universal Declaration of Human Rights, currently provides the most efficient system of human rights protection because it offers individuals the possibility of jurisdictional control regarding the respect of their rights (Sudre, 2005). The European Convention on Human Rights takes family under its wings. To be more accurate, the Convention protects the rights of individuals who form a family rather than family as an institution (Sudre, 2002). The Convention articles concerning family confirm this assessment: Article 8 protects the "right to respect for family life," article 12 guarantees the "right to marry," article 5 of Protocol 7 proclaims the "equality between spouses."

Children are protected under the European Convention, even though the latter does not contain specific provisions (De Boer-Buquicchio, 1988). Despite the fact that the European Convention does not explicitly aim at protecting children, children can apply to the Court claiming the violation of the rights guaranteed by the Convention. More precisely, according to article 1 of the European Convention, the Member States "shall secure to everyone within their jurisdiction the rights and freedoms defined" in the Convention. Children are undoubtedly included in the term "everyone" (Couturier- 
Bourdinière, 2004). Moreover, legal capacity is not required for applying to the European Court of Human Rights (Sudre, 2008) and hence, a child can apply to the Court without the intervention of his or her legal representatives (De Boer-Buquicchio, 1988; Reid, 1998). However, it is not easy for children to introduce an application to the European Court; they face a number of practical problems such as lack of knowledge of the Strasbourg procedure, difficulties in obtaining legal assistance, and lack of financial resources. Moreover, because of their young age, they may not be able to speak, write or understand what is happening to them (see Reid, 1998). Therefore, children themselves rarely apply to the European Court especially in relation to cases regarding family life. ${ }^{13}$ The majority of applications concerning children are introduced on their behalf by their parents or another member of their family. ${ }^{1415}$ Furthermore, a large number of applications are introduced by one of the parents who claims to be a victim of a Convention violation; their allegations indirectly influence their children. ${ }^{16}$.

Only one Convention article refers hastily to children in the context of family relationships. Article 5 of Protocol 7 mentions the interests of the child in relation to the equality between spouses but this article actually welcomes measures taken by Member States that impose a difference in treatment between parents while serving children's interests. No other Convention article includes the term 'child.' Only the terms 'minor' and 'juveniles' are used. In fact, article $5 \S 1 \mathrm{~d}$ ) regulates the detention of a 'minor' while article $6 \S 1$ authorizes the exclusion of the press and public from a trial in the interests of 'juveniles.' No Convention article establishes the best interests principle.

\section{Judges and Judgements}

Since the provisions of the European Convention and its Protocols are not sufficiently precise, the European Court of Human Rights concretizes them through its interpretation (Matscher, 1998). This interpretation is teleological because it is based on the objectives of the Convention as described in its Preamble. It is also dynamic and constructive, contributing to the development of the Convention rights and having article 32 of the European Convention and its Preamble as its basis (Matscher, 1998; Sudre, 2005; Sudre, 2001). Moreover, the European Court recalls that "the Convention is a living instrument which [...] must be interpreted in the light of present-day conditions" ${ }^{\prime \prime}$; therefore, the interpretation of the European Convention must be deprived of anachronisms while moral and social evolution must be taken into consideration (Sudre, 2008). 
The Convention's interpretation by the European Court is also unpredictable (Sudre, 2001). Its approach is changeable; it is case-based (Meulders - Klein, 1996). The European Court establishes certain principles relating to specific issues but the application of these principles in the context of each case is not the same because each case has its particularities. Hence, the Court's case law seems to a great extent inconsistent, without the possibility to predict, at least to a certain level, the content of its judgments. It is argued that even the most fervent supporters of the Strasbourg human rights protection system develop a feeling of insecurity emanating from the unpredictability of the Court's jurisprudence (Meulders-Klein, 1996).

\section{The Correlation between European and National Perspectives on Concepts of the Family and Child}

The European Convention seems to elaborate an individualistic philosophy illustrated by the concept of "the right to..." which is not easily compatible with the essence of family law, a law that organises the reciprocal prerogatives and duties of a group (Dekeuwer-Défossez, 2000). Additionally, the unpredictability of the European Court's case law seems more disturbing when it concerns Convention articles relating to family issues. Since family and children are so important for society, it is not easy to accept that one of the sources of the law applicable to them is not stable.

The European Convention and the European Court represent the European continent through the concepts of individualism and unpredictability while family law, as created in national legal systems, embodies the specific characteristics of each European country, namely, collectivism and legal certainty. However, having as starting point individual rights, the Strasbourg Judges forge an abundant case law on family issues. National parliaments make family legislation and national judges apply and interpret it. At the same time, the European human rights system sets up a new type of family law that could be considered European.

The main characteristic of this European jurisprudence is the concern for children and their best interests. In spite of the child's absence from the text of the European Convention, the dynamism of the European Court's case law places the child and his or her best interests under the Convention shield. The best interests principle, one of the most emblematic qualities of national family law, is at the heart of family life protection by the Strasbourg Court. Indeed, the Court has underlined that "consideration of what is in the best interest of the child is in any event of crucial importance" 18 ; that is, that "the 
child's interest must come before all other considerations" $" 19$ and that "there is currently a broad consensus - including in international law - in support of the idea that in all decisions concerning children, their best interests must be paramount." ${ }^{20}$ The European Judges appropriated this well known principle of national family law (Hamadi, 2007) and, consequently, European family law seems to start having its own best interests principle.

The best interests concept appeared early in the European case law, especially in cases relating to family relationships. It should be noted that the European Commission on Human Rights, when it existed, referred systematically to this notion. ${ }^{21}$ It should also be emphasized that the European Court refers systematically to article 3 of the United Nations Convention on the Rights of the Child ${ }^{22}$ in relation to family life cases, empowering its best interests analysis by using it as a source of interpretation. ${ }^{23}$ The Court $^{24}$ equally refers to General Comment $N^{\circ} 14(2013)^{25}$, where the Committee on the Rights of the Child ${ }^{26}$ provides clarification regarding the best interests concept.

These observations lead us to a series of questions: What is the content of the child's best interests on the European scene? Does the European human rights system elaborate with precision this content or establish certain guidelines? If the European public order, which is a notion established by judgment Loizidou v. Turkey ${ }^{27}$ (Sudre, 2008), includes a European family law, could one detect a European concept of the best interests of the child as well?

The European jurisprudence on family issues concerning children encompasses a variety of cases: child adoption, ${ }^{28}$ assisted reproductive technology, ${ }^{29}$ homosexual parents, ${ }^{30}$ transsexual parents, ${ }^{31}$ parents in prison, ${ }^{32}$ children born out of wedlock, ${ }^{33}$ foster care,${ }^{34}$ international child abduction, ${ }^{35}$ migrant children and parents, ${ }^{36}$ child custody and visitation rights, ${ }^{37}$ equality between parents, ${ }^{38}$ andpaternity issues. ${ }^{39}$.

The European Court acknowledges that the determination of the child's best interest is a task that belongs to the national authorities. ${ }^{40}$ However, the Court's control is always there, having at the same time certain limits. The Strasbourg Judges do not determine in a detailed way all the aspects of the child's best interests in a case presented before them. They forge its minimum content, its guidelines, and they set its 'pillars' with the Member States free to decide on this basis its exact content.

This conclusion illustrates the assessment according to which the European Court's case law is an instrument of harmonization of national human rights protection systems on the basis of a minimum content rooted in the European Convention (Sudre, 
2008). The Convention does not impose absolute uniformity; rather, an extensive variety of national solutions is acceptable. The doctrine of the margin of appreciation, constructed by the Court's jurisprudence, is based on this reality (Sudre et al, 2009). Consequently, in the European public order (Sudre, 2008), a European harmonization of family law is taking place because of the activity of the European Court that results in the creation of European family law (Rieg, 1990). This harmonization effect of the European case law concerning family relationships is also identified in the appreciation of the child's best interests within their context. The European Judges could never impose a uniform and detailed appreciation of the child's best interests; their mission of harmonization allows them to elaborate only its basic principles.

When the Strasbourg Judges do not agree with the national evaluation of the child's best interest and, therefore, with the national solution given to a particular case, they contribute with their judgment to the construction of the European minimum content of the child's best interest. However, even when the Court agrees with the national choice, it contributes as well to the European construction of the child's best interest as long as its argumentation is well motivated and dominated by a pedocentric spirit.

This European minimum content of the child's best interest contains two branches: the conceptual principles and the methods of evaluation. The analysis on the specific European Court's judgments that follows illuminates the construction of these two branches.

\section{A Concrete Example of the European Construction of the}

\section{'Best Interests of the Child.'}

Equality issues between divorced parents provided the European Court with the opportunity to build up important aspects of the child's best interests minimum content while handling them. According to the European jurisprudence, "the mutual enjoyment by parent and child of each other's company constitutes a fundamental element of family life, even if the relationship between the parents has broken down."41 This principle issued by the European Court pinpoints that a new family reality emerges from parents' divorce: the husband-wife relationship is gone but the parent-child relationship stays alive. Many divorced parents have the intention to actively participate in their children's lives despite the radical changes that their family has faced. It is precisely this change that imposes the reorganisation of family relationships: custody allocation and attribution of visitation rights inform this reorganisation. Parents often object to this distribution of roles, not only before the domestic courts, but also before the European Court. This 
reorganisation of parent-child relationships might become more complicated if one of the parents makes "non conventional" personal choices; that is, if he or she has an uncommonly accepted way of life relating to issues such as religion, sexual orientation, and transsexualism. 'Non conventional' parents often claim that the distribution of parental rights was determined by their unordinary way of life. In other words, the litigation regarding the reorganisation of the parent-child relationship obtains certain specificity when a question of discriminatory treatment against one of the parents is raised. Questions arise as to how the Court maintains balance between the importance given to the best interests principle and the necessity to respect equality between parents, and, secondly, on which grounds it seeks to identify the best interests of the child.

\section{Discrimination and Violations}

In the case of Hoffmann v. Austria, ${ }^{42}$ the applicant, a divorced mother, complained under articles 8 and 14 of the Convention that the Austrian Supreme Court had awarded preferential parental rights over her children to their father rather than to her because she is a Jehovah's Witness.

In assessing the best interests of the children, the Austrian Supreme Court considered the hazards attached to mother's refusal to consent to her children receiving a necessary blood transfusion in spite of the fact that a court could substitute its consent for that of the mother as well as the danger for the children to become social outcasts because of the principles and practices of the Jehovah's witnesses. To note, the mother was prepared to allow the administration of blood transfusions to the children if and when required by law and to allow children to celebrate holidays such as Christmas and Easter with their father. Furthermore, the Austrian Supreme Court admitted that transferring the children to the care of their father might cause them psychological stress but observed that this situation had to be accepted in their own best interests.

In this case, the European Court disapproved of the difference in treatment suffered by the applicant, even though it recognized that it aimed at protecting her children. The Court mainly criticized the fact that the decision of the Austrian Supreme Court was not based on the specific circumstances of the case but on the applicant's religion in the abstract (Hauser, 1994). The European Court sanctioned the Austrian Judge's reasoning to opt for a determination in abstracto of the children's best interests based on possible negative consequences of the mother's religion over her children (Sudre et al., 2009). When the European Court concluded that a reasonable relationship of proportionality did not exist between the means employed and the aim pursued, it 
referred to the anticipated criticism of the Austrian Supreme Court on the mother's religion and not to the excessive character of its decision in relation to its aim to protect the children (Sudre et al., 2009). The reasonable relationship of proportionality would be probably attained if the Austrian Supreme Court had based its decision on precise and concrete factors demonstrating the negative influence of the applicant's religion on her children (Sudre et al., 2009).

Moreover, the European Court referred to article 5 of Protocol 7, in spite of the fact that it was not in aid in the proceedings. The European Judges interpreted this provision observing that "it provides for the fundamental equality of spouses inter alia as regards parental rights and makes it clear that in cases of this nature the interests of the children are paramount." 43 Therefore, according to the European Court, the necessity to safeguard children's best interests legitimizes a difference in treatment between spouses in relation to parental rights.

In the Hoffmann case, the Strasbourg Court confirmed that the child's best interest is the primary consideration in proceedings regarding the attribution of parental rights after divorce. Second, the Court established a guideline principle concerning the appreciation of the child's best interests; it pinpointed the formula that leads to its adequate evaluation: determination in concreto. Prejudices, probabilities, stereotypes, vague and general fear, and "passe-partout" solutions have to be put aside. A determination in abstracto would not only result in a discriminatory difference in treatment against the 'non-conventional parent,' it would be based solely on his or her personal life choices that would automatically enframe their relationship with their child, but it would also reorganize the parent-child relationship in a pattern that would not be in the child's best interests.

The European Court follows the Hoffmann reasoning and solution in the case Palau-Martinez v. France, ${ }^{44}$ where the applicant, a Jehovah's Witness divorced mother, alleged that a decision by the French courts to establish her two children's residence with their father was based solely on her religion.

The Palau-Martinez case provided some interesting clarifications concerning the role of the social inquiry report in the appreciation of the child's best interests, the latter being the central issue of the case. Nonetheless, it has been unjustifiably argued that, in this case, "the mother's religion was the determining factor and the child's rights were held to be of secondary concern" (Lee, 2008, pp. 73 - 74). 
The French Judges did not grant the mother's request for a social inquiry report, despite the fact that, according to the European Court, "such an inquiry would no doubt have provided tangible information on the children's lives with each of their parents and made it possible to ascertain the impact, if any, of their mother's religious practice on their lives and upbringing.,"45

The European Court did not impose an obligation for the national judge to grant a request for a social inquiry report, every time such a request is submitted regarding family litigations (Gouttenoire, 2004). Nevertheless, it is obvious that the European Court highlighted the importance of a social inquiry report in the effective determination of the best interests of the child. The European disapproval of the French court's refusal to grant this request was based on the usefulness that such a measure would have for the evaluation of the best interests of the applicant's children (Gouttenoire, 2004). More precisely, because of this refusal, the French courts deprived themselves of an excellent tool that would have helped them to appreciate in concreto the children's best interests and instead, opted for a general and abstract evaluation of the situation (Gouttenoire, 2004).

In the case Vojnity v. Hungary ${ }^{46}$, where the applicant, a divorced father, complained that the absolute ban on his access rights in respect of his son had been based on his adherence to the religious denomination Congregation of the Faith, the European Court adopted the Hoffmann approach and went a step further. On the basis of the rights to respect for family life and religious freedom as enshrined respectively in articles 8 and 9 of the Convention, together with the right to respect for parents' philosophical and religious conviction in education, as provided in article 2 of Protocol 1 to the Convention, the Court confirmed the right of married and separated or divorced parents who do not have custody of their children to communicate and promote their religious convictions to them, even in an insistent or overbearing manner, unless this exposes the children to dangerous practices or to physical or psychological harm. In the Vojnity case, the disregard of the principle of proportionality amounted not only to the determination in abstracto by the Hungarian courts of the best interest of the child, since there had been no convincing evidence that the applicant's religious convictions exposed his son to any kind of harm, but also to the severity of the measure, since it had been very restrictive to the father's detriment; less severe alternatives had not been taken into consideration and there were no exceptional circumstances justifying such a radical measure. 
The Hoffmann approach was also adopted by the European Court in the case of Salgueiro Da Silva Mouta v. Portugal, ${ }^{47}$ where the applicant, a father living after his divorce with another man, complained that the Portuguese courts awarded parental responsibility for his daughter to his former wife rather than to himself exclusively on the grounds of his sexual orientation.

More specifically, the Strasbourg Court noted that the applicant's homosexuality was a decisive factor in the decision to grant parental responsibility to the mother, since the Portuguese Judges were of the opinion that the child should live in a "traditional Portuguese family;" 48 they wondered whether homosexuality is or is not an "illness",49 and reached the conclusion that it is definitely an "abnormality" from which children must be kept away and, while ruling on the applicant's right to contact, they warned him not to adopt conduct which might make the child realize that he is homosexual. It must be taken into consideration that, during the national procedure, the court psychologists stated in their report that the child had a very good relationship with her father, who was very affectionate, attentive and kind towards her.

\section{Absence of discrimination and non-violation}

In cases where the allegations of 'non-conventional parents' who claim a discriminatory difference in treatment in the allocation of parental rights are rejected, the European Court also confirms vice versa the formula that results in the proper determination of the best interests of the child. In the case Ismailova v. Russia. ${ }^{51} \mathrm{a}$ Jehovah's Witness divorced mother complained that the decisions of the domestic courts to grant custody of her two children to their father were based on her religious beliefs. After their parent's separation, the children had only occasional contact with their father. However, during a visit to their paternal grandparents, the grandparents refused to return them to their mother who had no regular access to the children since then. The proceedings before the Russian courts resulted in their decision to grant custody of the children to their father.

After referring in a detailed way to the decisions of the Russian courts, the European Court, first of all, dissociated the Ismailova case from the solution adopted in the Palau-Martinez judgment and acknowledged that the national decisions were exclusively based on the best interests of the children. It underlined that these decisions were not based solely or principally on the applicant's religion since the domestic courts took into consideration the children's age, the parents' financial status and the housing 
conditions that each of them could offer to the children. More precisely, the children were 9 and 5 years old at that time and the domestic courts observed that they had been living with their father for more than five years and had not yet attained the age of 10; moreover, the father's financial status and housing conditions were considered better than those of the mother.

The Strasbourg Court noted that the Russian courts relied on direct and concrete evidence demonstrating the negative influence of the applicant's religion on her children. According to them, the mother had included her children in her religious practices, failed to protect them and this had led to social and psychological repercussions for them. More specifically, it was established that the children were attending meetings of Jehovah's Witnesses after which they became shy and irritable, they perceived the surrounding world and natural phenomena in the way the teaching of this religion presents it, for example, fearing a 'worldwide flood' whenever it rained; they called their paternal grandmother "Satan" and would not attend their classmates' birthdays or other celebrations because the religion did not permit it.

The European Court estimated that a reasonable relationship of proportionality existed between the difference in treatment suffered by the applicant and the aim to protect her children's best interests; the national courts' reasoning was neither arbitrary nor unreasonable.

The Strasbourg Court remained loyal to the principle of determination in concreto of the child's best interests established by the Hoffmann case. Nonetheless, in the Ismailova case, the application of this principle did not lead the Court to conclude to a Convention violation. The Strasbourg Judges estimated that this time, the national solution had a solid base: an adequate evaluation of the children's best interests based on the concrete circumstances of the case.

However, the Court did not hold unanimously that there had been no violation of article 8 and 14 of the Convention. The three dissenting Judges were of the opinion that the applicant suffered a difference in treatment because of her religion and that the Ismailova case should not be dissociated from the solution given in the Hoffmann and the Palau-Martinez cases. They mainly underlined that "the requirement of a tolerant society is to respect the religious convictions of the mother that may accordingly affect her children's education." 52

The Judges also noted that the Russian courts did not take into adequate consideration the age of the children, especially that of the youngest child who should 
have stayed with her mother. Furthermore, they considered that the domestic courts did not pay enough attention to certain factors such as the parenting skills of the mother, who was a teacher, and were never doubted, while the father, who was a seaman and absent for half the year and for a certain period of time before the divorce, had failed systematically to provide financial support for the children. They concluded that "even if there are no direct negative declarations about the Jehovah's Witnesses to be found in the national courts' judgments, the arguments concerning the implications of the applicant's religious affiliation on the children's upbringing suggest that the case might have been decided differently had it not been for the applicant's religion.

The analysis of the three dissenting Judges incites debate. Did the majority Judges draw a conclusion very easily, endorsing hastily the national evaluation of the children's best interests? Did this evaluation take into proper consideration all the crucial elements of the case? On the one hand, it is undisputed that the European Court's mission is very difficult because it has no direct contact with the specific circumstances of each case; on the other hand, we should admit that the dissenting Judges' arguments do not lack pertinence. It seems that the cautious argumentation of the domestic courts saved Russia from Strasbourg Court sanctions since there was no direct "attack" towards the mother's religious beliefs (Muzny, 2008).

In the case P.V. v. Spain ${ }^{54}$, the applicant, a male-to-female transsexual, claimed that her visitation rights over her son were restricted because of her transsexualism. The European Court approved of the restriction imposed by the national courts on the applicant's visitation rights and refused to sanction Spain, because, in its view, the Spanish Judges took their decision on the basis of a concrete analysis of the child's best interests in the context of the case (Gouttenoire, 2011).

Before her gender reassignment, the applicant had been married and had a son. After the couple's separation, the custody of the child was awarded to the mother and the parental responsibility to both parents jointly. Contact arrangements were made for the applicant. Soon the mother sought to have the father deprived of parental responsibility and to have the contact arrangements suspended, alleging mainly that the applicant was undergoing treatment with a view to gender reassignment; she was wearing make up and dressing like a woman. Taking into account a psychological expert's report that noted the applicant's emotional instability and the risk that it might be passed on to the child, who was 6 years old at the time, the first-instant Judge decided only to restrain the contact arrangements. The applicant appealed without success against this decision. The court of 
appeal pointed out that the initial contact arrangements could jeopardize the child's emotional balance since they had to get progressively used to the idea that his father was changing his sex. Moreover, the applicant's amparo appeal before the Constitutional Court was dismissed. It needs to be noted that before the dismissal of this appeal, the applicant was granted, after her request, more favourable contact arrangements.

After a meticulous study of the domestic courts reasoning, the European Court, dissociating the facts of the P.V. case from those of the Salgueiro Da Silva Mouta case, noted that the reason for the restriction of the applicant's visitation rights was not an abstract assessment of the child's best interests based on her transsexualism but the concern for the child's well-being, as viewed in the specific circumstances of the case. Furthermore, the Strasbourg Court underlined that the domestic courts did not deprive the applicant of parental responsibility and did not suspend the contact arrangements as the mother had requested; additionally, when it was considered appropriate, they modified the contact arrangements in favour of the applicant.

The Spanish courts determined in concreto the child's best interests. This approach had a double beneficial effect for the child. First, it respected the relationship between father and child as such; the child was not deprived of his father and their contact was maintained, even if it was not always very frequent; second, the respect of this relationship was based on a dialectic approach containing two steps: restrict the contact between father and child when the protection of the child's well-being demands it, and enlarge visitation rights when the child's best interests permits it. Hence, the Spanish courts managed to adequately balance the applicant's parental rights and her son's best interests, creating a situation that contributed to the positive evolution of their relationship. The European Court acknowledged this successful effort.

\section{Conclusion}

This article has argued that the European minimum content of the child's best interest contains two branches: the conceptual principles and the methods of evaluation. The analysis of the cases concerning equality between divorced parents in parental rights allocation provide concrete example of the construction of these two branches.

More specifically, the European Court, within the context of these cases, forges the minimum content of the child's best interests by establishing a conceptual principle: the assessment of the best interests of the child determines the destiny of parental rights. In cases where an equality issue between parents emerges in particular, it is on the basis 
of the child's best interests that a difference in treatment could be justified or condemned by the ECtHR. We could say that the Court builds on the notion of "effective equality" between parents. The notion of "effective equality" amounts to the following situation: when a divorced 'non-conventional parent is in the same situation with the other parent but he or she is being treated differently, this difference in treatment is acceptable if proper best interests determination has previously taken place. On the contrary, when a divorced 'non-conventional parent' is in the same situation with the other parent, and he or she is being treated differently, this difference in treatment is discriminatory, if suitable best interests appreciation is absent.

This model of "effective equality" between parents, or to be more accurate, between spouses, is confirmed by article 5 of Protocol 7, which notes in its second subparagraph, that the equality between spouses proclaimed in its first subparagraph, does not prevent States from taking measures necessary in the interests of the children.

Furthermore, the European Court continues elaborating the minimum content of the child's best interests by indicating a method of evaluation that reassures its adequate determination. More precisely, it opts for an appreciation in concreto and rejects an appreciation in abstracto. The European Court does not define the exact content of the child's best interests; it points out the suitable way to follow in order to determine effectively children's best interests. It does not sanction the national solution as such, but the reasoning and the choices that led to it.

By adopting this approach, the European Court sets up the foundations of the European notion of the best interests of the child and allows the Council of Europe Member States freedom to complete its construction. It does not intrude; it does not menace the Member States' autonomy by imposing rules in such a delicate domain as is the protection of children within family life. It demonstrates to the Member States the basic steps to be followed in order to enhance their human rights protection systems and recognizes their untouchable right to handle family relationships within their jurisdictions. The European Court's jurisprudence regarding the protection of children and family life is a tool that helps Member States to correct their mistaken approaches and solutions; it is not a form of punishment or threat that could annul their right to decide for highly important issues attached to their culture and identity. 
Notes

${ }^{1}$ Kyriaki Patsianta is a Barrister in Greece specializing in European Human Rights Law, and in children's rights in particular. The basic core of this manuscript was the topic of a guest lecture she gave at Exeter Law School-UK.

${ }^{2}$ For example, this is the case in France and Greece.

${ }^{3}$ Regulations on marriage and parental authority provide such an example.

${ }^{4}$ For instance, this is the case for the protection of family ties created out of wedlock or the possibility to perform a same-sex marriage.

${ }^{5}$ The Geneva Declaration of the Rights of the Child adopted by the League of Nations in 1924 and the Declaration of the Rights of the Child adopted by the UN General Assembly in 1959 were not legally binding.

${ }^{6}$ See notably the work of the Committee on the Rights of the Child that is the body of independent experts that monitors the implementation of the Convention on the Rights of the Child, http://www.ohchr.org/EN/HRBodies/CRC/Pages/CRCIndex.aspx

${ }^{7}$ See supra, at page 4 .

${ }^{8}$ See http://indicators.ohchr.org/

${ }^{9}$ See supra, note 5 .

${ }^{10}$ General comment No. 14 (2013) on the right of the child to have his or her best interests taken as a primary consideration (art. 3, para. 1), 29 May 2013, CRC/C/GC/14, § 4.

${ }^{11}$ Ibid., $\S 6$.

12 The Convention was signed in Rome on the $4^{\text {th }}$ of November 1950 and came into force on the $3^{\text {rd }}$ of September 1953.

${ }^{13}$ For instance, see ECtHR, Mikulić v. Croatia, 7 February 2002.

${ }^{14}$ For instance, see ECtHR, Marckx v. Belgium, 13 June 1979, published in A31.

${ }^{15}$ For instance, see European Commission on Human Rights, Price v. The United Kingdom (decision), 9 Mars 1988, application number 12402/86.

${ }^{16}$ For example, see cases relating to the respect of divorced parents' visitation rights such as ECtHR, Glaser v. The United Kingdom, 19 September 2000.

${ }^{17}$ ECtHR, Tyrer v. The United Kingdom, 25 April 1978, published in A26, § 31.

${ }^{18}$ ECtHR, Johansen v. Norway, 7 August 1996, published in Reports 1996-III, § 64.

${ }^{19}$ ECtHR, Gnahoré v. France, 19 September 2000, § 59. 
${ }^{20}$ For example, see ECtHR, Neulinger and Shuruk v. Switzerland (Gr. Ch.), 6 July 2010, $\S 135$.

${ }^{21}$ For example, see European Commission on Human Rights, X. v. Austria (decision), 5 January 1960, application number 514/59.

${ }^{22}$ See supra, at page 6.

${ }^{23}$ For example, see ECtHR, Neulinger and Shuruk v. Switzerland (Gr. Ch.), 6 July 2010, $\S 135$.

${ }^{24}$ For example, see ECtHR, S.L. and J.L. v. Croatia, 7 May 2015, § 43, which does not concern, however, the right to respect for family life but the protection of property (article 1 of Protocol 1 to the Convention) and, more specifically, the protection of the child's best interests in a property deal.

${ }^{25}$ See supra, at page 6 .

${ }^{26}$ See supra, note 5 .

${ }^{27}$ ECtHR, Loizidou v. Turkey, 23 Mars 1995, published in A310, $\S 75$ and 93.

${ }^{28}$ For example, see ECtHR, Gas and Dubois v. France, 15 March 2012.

${ }^{29}$ For example, see ECtHR, Dickson v. The United Kingdom (Gr. Ch.), 4 December 2007.

${ }^{30}$ For example, see ECtHR, Salgueiro Da Silva Mouta v. Portugal, 21 December 1999.

${ }^{31}$ For example, see ECtHR, P.V. v. Spain, 30 November 2010.

${ }^{32}$ For example, see ECtHR, Sabou and Pircalab v. Romania, 28 September 2004.

${ }^{33}$ For example, see ECtHR, Fabris v. France (Gr. Ch.), 7 February 2013.

${ }^{34}$ For example, see ECtHR, K. and T. v. Finland (Gr. Ch.), 12 July 2001.

${ }^{35}$ For example, see ECtHR, Neulinger and Shuruk v. Switzerland (Gr. Ch.), 6 July 2010.

${ }^{36}$ For example, see ECtHR, Mubilanzila Mayeka and Kaniki Mitunga v. Belgium, 12 October 2006.

37 For example, see ECtHR, Zaunegger v. Germany, 3 December 2009.

${ }^{38}$ For example, see ECtHR, Vojnity v. Hungary, 12 February 2013.

${ }^{39}$ For example, see ECtHR, Różański v. Poland, 18 May 2006.

${ }^{40}$ ECtHR, Kosmopoulou v. Greece, 5 February 2004, § 48: “[...] As regards the child's interest, the Court observes that it is not for it to say how the domestic courts should have evaluated that issue $[\ldots]$ ".

${ }^{41}$ For example, see ECtHR, Elsholz v. Germany, 13 July 2000, § 43.

${ }^{42}$ ECtHR, Hoffmann v. Austria, 23 June 1993, published in A255 - C. 
${ }^{43}$ Ibid., $\S 35$.

${ }^{44}$ ECtHR, Palau - Martinez v. France, 16 December 2003.

${ }^{45}$ Ibid., $\S 42$.

${ }^{46}$ ECtHR, Vojnity v. Hungary, 12 February 2013.

${ }^{47}$ ECtHR, Salgueiro Da Silva Mouta v. Portugal, 21 December 1999.

${ }^{48}$ Ibid., $\S 34$.

${ }^{49}$ Ibid.

${ }^{50}$ Ibid.

${ }^{51}$ ECtHR, Ismailova v. Russia, 29 November 2007.

52 Dissenting opinion of Judge Hajiyev, joined by Judges Vajić and Steiner, annexed to the judgment Ismailova v. Russia, 29 November 2007, p. 17.

${ }^{53}$ Ibid., p. 18.

${ }^{54}$ ECtHR, P.V. v. Spain, 30 November 2010.

\section{References}

Arnaud, A. J. (1996). Philosophie des droits de l'homme et droit de la famille. In Françoise Dekeuwer- Défossez and Marie- Thèrese Meulders- Klein (eds.), Internationalisation des droits de l'homme et évolution du droit de la famille (325). Paris: LGDJ, 16.

Conseil de l'Europe. (1990). La protection des enfants mineurs dans le cadre de la Convention européenne des droits de l'homme, Analyse de jurisprudence. Strasbourg: Conseil de l'Europe.

Couturier- Bourdinière L. (2004). La Convention européenne des droits de l'homme et la protection des droits des enfants. In Libertés, justice, tolérance : Mélanges en hommage au Doyen Gérard Cohen-Jonathan (523- 549). Bruxelles: Bruylant.

De Boer- Buquicchio, M. (1988). Children and the European Convention on human rights. In Franz Matscher and Herbert Petzold (eds.), Protecting Human Rights: The European Dimension: Studies in honour of Gérard J. Wiarda (73-89). Köln: Carl Heymanns Verlag KG.

Dekeuwer- Défossez, F. (2004). Les droits de l'enfant. Paris: Presses Universitaires de France. 
Dekeuwer -Défossez, F. (2000). Préface. In La famille et la Convention européenne des droits de l'homme (no pagination). Paris: L'Harmattan.

De Lamy, B. (1998). Une nouvelle source du droit de la famille : la Convention européenne des droits de l’homme. Droit de la famille, n³, 9- 10.

Donnier, M. (1959). L'intérêt de l'enfant. Recueil Dalloz, 179-182.

Fulchiron, H. (1996). Les Conventions internationales, présentation sommaire. In Jacqueline Rubellin - Devinchi and Frank Rainer (Eds.), L'enfant et les Conventions internationales (19- 33). Lyon: Presses Universitaires de Lyon.

Gouttenoire, A. (2011). La famille dans la jurisprudence de la Cour européenne des droits de l'homme. Droit de la famille, $\mathrm{n}^{\circ} 4,10-15$.

Gouttenoire, A. (2004). L'obligation de statuer in concreto en matière religieuse ou de la nécessité pour le juge aux affaires familiales d'utiliser son pouvoir d'appréciation à bon escient ?. La Semaine Juridique Edition Générale, n³0, 1386-1390.

Habib, B. (1983). La définition de l'enfant en droit international public. In Maurice Torrelli (ed.), La protection internationale des droits de l'enfant (65-90). Paris: Presses Universitaires de France.

Hamadi, H. (2007). Le statut européen de l'enfant. In Le droit et les droits de l'enfant (161-192). Paris: L'Harmattan.

Hauser, J. (1994). Violation de l'article 8 combiné avec l'article 14 de la Convention européenne des droits de l'homme par une juridiction nationale ayant confié la garde des enfants au père en raison de l'appartenance de la mère à la communauté religieuse des témoins de Jéhovah. Recueil Dalloz, 326-329.

Kounougeri-Manoledaki, E. (2008). Family Law. Athens: Editions Sakkoula (in Greek). Labayle, H. (2007). La diversité des sources du droit à une vie familiale. In Jean Jacques Lemouland and Monique Luby (eds.), Le droit à une vie familiale (1-15). Paris: Dalloz.

Lambert, P. (2002). La définition de la vie familiale. In Frédéric Sudre (ed.), Le droit au respect de la vie familiale au sens de la Convention européenne des droits de l’homme (55- 59). Brussels: Némésis.

Lee, R. (2008). Custody Disputes and Alternative Religions in the Courts of England and Wales. Journal of Contemporary Religion, 23, 63-76.

Matscher, F. (1998). Les contraintes de l'interprétation juridictionnelle, les méthodes d'interprétation de la Convention européenne. In Frédéric Sudre (ed.), 
L'interprétation de la Convention européenne des droits de l’homme (15- 40). Bruxelles: Némésis.

Meulders- Klein, M. T. (2003). L'enfant et les conventions internationales, enfant sujet? enfant objet ?. In Jean- Louis Renchon (Ed.), L'enfant et les relations familiales internationales (401-411). Brussels: Bruylant.

Meulders-Klein, M. - T. (1996). Internationalisation des droits de l'homme et évolution du droit de la famille : un voyage sans destination ?. In Françoise DekeuwerDéfossez and Marie- Thèrese Meulders- Klein (eds.), Internationalisation des droits de l'homme et évolution du droit de la famille (179-213). Paris: LGDJ.

Muzny, P. (2008). Lorsque la Cour européenne succombe aux préjugés. Recueil Dalloz, 2843-2847.

Papachristos, A. (1998). Manual on family law. Athens: Editions Ant. N. Sakkoula (in Greek).

Reid, K. (1998). Article 25 of the Convention: applications by children. In Michele De Salvia and Mark Villiger (eds.), The Birth of European Human Rights Law: Studies in honour of Carl Aage Nørgaard (301-307). Baden - Baden: Nomos Verlagsgesellschaft.

Rieg, A. (1990). L'harmonisation européenne du droit de la famille : mythe ou réalité ?.

In Walter A. Stoffel and Paul Volken (eds.), Conflits et harmonisation : Mélanges en l'honneur d'Alfred E. Von Overbeck (473-499). Fribourg: Editions Universitaires Fribourg Suisse.

Roussel, L. (1991). L'enfant dans la famille incertaine. In Annette Jacob (ed.), Les droits de l'enfant : quelle protection demain ? (233-249). Paris: Lierre et Coudrier.

Rubellin - Devichi, J. (1994). The best interests principle in French law and practice. In Philip Alston (ed.), The best interests of the child, Reconciling culture and human rights (259-280). New York: Oxford University Press.

Smychzynski, T. (1983). La définition de la famille en droit international public. In Maurice Torrelli (ed.), La protection internationale des droits de l'enfant (91102). Paris: Presses Universitaires de France.

Sudre, F., Marguénaud, J. P., Andriantsimbazovina, J., Gouttenoire, A. and Levinet M. (2009). Les grands arrêts de la Cour européenne des droits de l'homme. Paris: Presses Universitaires de France. 
Sudre, F. (2001). A propos du dynamisme interprétatif de la Cour européenne des droits de l’homme. La Semaine Juridique Edition Générale, n²8, 1365-1368.

Sudre F. (2002). La « construction » par le juge européen du droit au respect de la vie familiale. In Frédéric Sudre (ed.), Le droit au respect de la vie familiale au sens de la Convention européenne des droits de l’homme (11- 54). Bruxelles: Némésis.

Sudre, F. (2005). La Convention européenne des droits de l'homme. Paris: Presses Universitaires de France.

Sudre, F. (2008). Droit européen et international des droits de l'homme. Paris: Presses Universitaires de France.

Théry, I. (2002). Approche sociologique de la « vie familiale » : la question des définitions. In Frédéric Sudre (ed.), Le droit au respect de la vie familiale au sens de la Convention européenne des droits de l'homme (61-105). Brussels: Némésis.

Vasseur - Lambry, F. (2000). La famille et la Convention européenne des droits de l'homme. Paris: L'Harmattan.

Wolfson, S. (1992). Children's rights: the theoretical underpinning of the « best interests of the child ». In Michael Freeman and Philip Veerman (eds.), The ideologies of children's rights (7-27). Dordrecht: Martinus Nijhoff Publishers. 